\title{
Characteristics of the extreme rainfall event and consequent flash floods in W Slovenia in September 2007
}

\author{
S. Rusjan ${ }^{1}$, M. Kobold ${ }^{2}$, and M. Mikoš ${ }^{1}$ \\ ${ }^{1}$ Faculty of Civil and Geodetic Engineering, University of Ljubljana, Ljubljana, Slovenia \\ ${ }^{2}$ Environmental Agency of the Republic of Slovenia, Ministry of the Environment and Spatial Planning, Ljubljana, Slovenia
}

Received: 23 December 2008 - Revised: 11 May 2009 - Accepted: 8 June 2009 - Published: 23 June 2009

\begin{abstract}
During a weather front that passed over large parts of Slovenia on 18.9.2007, extreme rainfall events were triggered causing several severe flash floods with six casualties. Out of 210 municipalities in Slovenia, 60 were reporting flood damages, and the total economic flood damage was later estimated at close to 200 million Euro; highest damage was claimed by Železniki municipality in NW Slovenia. The main purpose of the study presented in this paper was to put together available meteorological and hydrological data in order to get better insight into temporal and spatial dynamics and variability of the flash flood event along the Selška Sora River flowing through the town of Železniki. The weather forecast by the Environmental Agency of the Republic of Slovenia (ARSO) lead to early warning of floodings but has underestimated rainfall amounts by a factor of 2. Also meteorological radar underestimated ground rainfall as much as by $50 \%$. During that day, in many rainfall gauging stations operated by ARSO in the area under investigation, extreme rainfall amounts were measured, e.g. $303 \mathrm{~mm}$ in $24 \mathrm{~h}$ or $157 \mathrm{~mm}$ in $2 \mathrm{~h}$. Some of the measured rainfall amounts were the highest registered amounts in Slovenia so far. Statistical analysis using Gumble distribution was performed and rainfall return periods were estimated. When assessing rainfall return periods, a question of the sampling error as a consequence of short rainfall records used was raised. Furthermore, measured rainfall data were used to reconstruct hydrographs on selected water stations along the Selška Sora River. The cumulative areal precipitation for the Selška Sora River catchment upstream of Železniki amounted to $219 \mathrm{~mm}$, while the modeled effective precipitation used to simulate the hydrograph peak was only $57 \mathrm{~mm}$. The modeled direct runoff coefficient therefore amounts to 0.26 . Surprisingly low value is mainly caused by the applied unit hydrograph method that
\end{abstract}

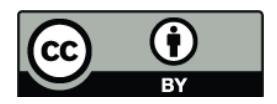

Correspondence to: M. Mikoš (mmikos@fgg.uni-lj.si) seeks to meet the peak discharge rather than hydrograph volume. However, the spatial distribution of the rainfall in the area was highly variable and present spatial positioning of rain gauges is obviously inadequate for proper representation of the actual spatial amount of rainfall. The study confirmed that post-flood investigation should focus on discharges and hydrological response of the catchment rather than simply analyzing statistical characteristics of rainfall.

\section{Introduction}

Post-event analyses of extreme rainfall events are gaining importance in the last years trying to incorporate systemization and standardization into the post-event surveys and investigations (Gaume and Borga, 2008). Information about the statistical characteristics of the event as a part of such postevent surveys in combination with available field data provides fundamental basis for designing, implementation and operation of measures and instruments for effective and sustainable flood risk reduction. The evaluation of extreme flood events is therefore an important basis for learning processes during ex-post evaluation of interventions in support of future development of strategies and strategic options in flood risk management (Norbiato et al., 2007). Flash floods should be considered as a special case due to their characteristics; they are localized phenomena that occur in basins of few hundred square kilometers or less, with response times of a few hours or less (Borga et al., 2007). Owing to usual scarcity of field data for the description of the flash flood events, rainfall frequency estimates are often used to describe the characteristics of a flash flood event. In these cases, the return period of the greatest point rainfall intensity within the storm is taken as the return period of the storm (Ramos et al., 2005). However, return periods defined in this manner can be very subjective and questionable as the rainfall intensity within the event can vary greatly depending on the

Published by Copernicus Publications on behalf of the European Geosciences Union. 
selection of the rainfall duration. Additional problem is the lack of reliable rain gauge coverage which frustrates the hazard characterization of flash flood generating storms developing at space and time scales that conventional rain observation system are not able to monitor (Creutin and Borga, 2003). On the other hand, in the case of the flash flood events, focus is on discharges rather than rainfall rates; to evaluate a flash flood return period discharge estimates are frequently considered (e.g. Costa and Jarrett, 2008; Gaume and Borga, 2008). A literature review of post-event studies can be found in Gaume et al. (2004).

Real-time observations, combined with hydrometeorological models, allow increasingly accurate and timely forecasts and warnings. Meteorological features, such as precipitation intensity, distribution and amounts, as well as hydrologic responses to these variables, are being incorporated into models aimed at improving understanding of rainfall-runoff relationships, upon which forecasts and warnings are based (Rochette and Moore, 1996; Schwein, 1996; Montz, 2001). The more we understand these factors, particularly the relationships between them in small watersheds, the greater the improvements in forecasts and warnings will be. However, the straightforward description of the situation is usually masked by characteristics of the meteorological and hydrological systems generating flash flood conditions. As Kelsch et al. (2001) pointed out, high intensity rainfall is more important than the total accumulation on small, fast-response basins. This is observed in flash floods in arid and semiarid situations (and also in urban environments). However, its generality is questionable in more humid hydroclimatic environments such as in $\mathrm{W}$ Slovenia (see Borga, 2007; Gaume, 2004; Delrieu et al., 2005). Basin characteristics are easily as important as the rainfall characteristics for determining the nature of the runoff. In addition, the conditions creating flash floods differ, even at the same location (Ogden et al., 2000). Thus, rainfall timing as well as intensity can be critical, and work must continue towards understanding general relationships from studying specific events (Baldini et al., 1995).

Almost every year local heavy rain showers and flash floods appear in different parts of Slovenia. Flash floods in September 2007 caused, besides high material damage of 210 million Euro, loss of six human lives. The meteorological forecast predicted precipitation for Tuesday, 18 September, but not in the quantity and intensity as it happened. Although intense storms and resulting flash floods are not something new in the region considered, the knowledge of their physical characteristics is still very limited. Their reduced spatial extension is often captured incorrectly by conventional observation including rain and river observation networks. Moreover, similarly as discussed by Ruin et al. (2008), the reliability of the data and the integrity of the measurement devices are often vigorously affected by high storm intensity, which reflects on both, rainfall and discharge measurement accuracy.
In a climatic sense, Slovenia presents a transitional area between different climatic types. Alpine climatic characteristics can be found in the NW part, sub-Mediterranean climate is characteristic for the SW part whereas towards the east, the continental climatic characteristics start to prevail. The variability of climatic characteristics at relatively short distances can be associated especially to distinctively high topographic variability which influences the occurrence of heavy rainfall events. Some parallels can be drawn to the seasonal distribution of heavy rains for the Mediterranean which exhibits a maximum in the late summer and during autumn. Doswell et al. (1998) explains that this distribution is strongly determined by (1) the Mediterranean area that especially in autumn is warm and wet in the lowest $2000 \mathrm{~m}$, leading to convective instability, and (2) the passage of largescale disturbances that induce vertical lifting and strong horizontal moisture advection that is necessary to continuously feed the precipitation systems.

However, the quantitative prediction of heavy rain periods remains a major challenge for forecasters and research meteorologists (Fritsch et al., 1998). Maddox et al. (1979) and Chappell (1986) analyzed the formation of numerous quasistationary convective systems in the US that produced flash flooding in terms of upper and low-level disturbances and rain generation mechanisms. As we will discuss later more in detail, in the case of Slovenia, due to high spatial topographic heterogeneity, the quantification of heavy rainfalls becomes even more challenging task.

This paper presents a description of meteorological conditions which led to catastrophic hydrological situation and raging power of the nature, as experienced in the large part of Slovenia in September 2007. The worst flood situation was observed in the catchment of the Selška Sora River, and especially in the town of Železniki that is discussed more in detail (Fig. 1). This area was hit by 4 floods in the last two decades (1990, 1995, 1998, 2007) (Robič, 2008).

The main aim of the study performed was to put together available meteorological and hydrological data in order to get better insight into temporal and spatial dynamics and variability of this flash flood event. The paper is structured as follows: Sect. 2 is an overview of the hydrometeorological situation and data assemblage: a synoptic situation, weather forecast and rainfall estimation are given followed by a description of the hydrological situation and discharge data. Section 3 brings results and discussion stressing: statistical analysis of the rainfall event, hydrological situation and consequences of the flash flood event. Section 4 completes the paper with conclusions. 


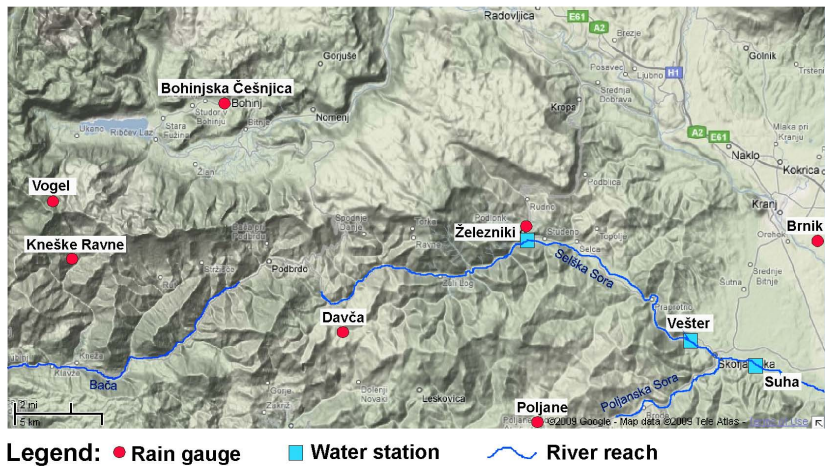

Fig. 1. Detailed map of the area around the town of Železniki with locations of raingauges and water station operated by ARSO.

\section{Overview of the hydrometeorological situation and data assemblage}

\subsection{Synoptic situation, weather forecast and rainfall es- timation}

Early on 18.9.2007, a highly baroclinic weather situation prevailed over Europe, and a sharp and elongated cold front was moving from the west towards the Alps. At 06:00 UTC (08:00 local time) on that day the prefrontal SW moist winds caused quasi-stationary convection over the north-western parts of Slovenia that lasted for almost $12 \mathrm{~h}$ (Strajnar, 2008). The first precipitation zone moved over W Slovenia towards east on 18.9.2007 between 03:00 and 05:00 UTC (05:00 and 07:00 local time) followed by a short break. After 8 a.m. some thunderstorms appeared in the hilly area of $\mathrm{W}$ Slovenia. Very heavy rain showers arisen after 9 a.m. A strong thunderstorm line was established and located there for nearly two hours. Next distinctive stationary thunderstorm line was built at 13:30 in a direction SW-NE over the same, NW part of Slovenia. New thunderstorm cells were formed over and over again during the afternoon and precipitation spread and strengthened towards NE part of Slovenia. Wind had started to blow in lower atmosphere from northeast to northwest. New thunderstorms were formed repeatedly when the cold front was passing and moving towards the south. Precipitation stopped in W part of Slovenia around 9 p.m., in NW at midnight, and in SE during 2 and 3 a.m. next morning (Vertačnik, 2008).

During the movement of this weather front that passed over large parts of Slovenia on that day, in many rainfall gauging stations operated by ARSO, extreme rainfall amounts were measured. The maximum measured $24 \mathrm{~h}$ accumulation was $303 \mathrm{~mm}$ at the Vogel Mountain in NW Slovenia, while the most affected area was along Selška Sora River upstream the town of Železniki, where rainfall rates reached up to $70 \mathrm{~mm} / \mathrm{h}$ and $100 \mathrm{~mm}$ in $2 \mathrm{~h}$ (Fig. 1).

The operational high-resolution limited area model (LAM) hydrostatic model ALADIN/SI with a $9.5-\mathrm{km}$
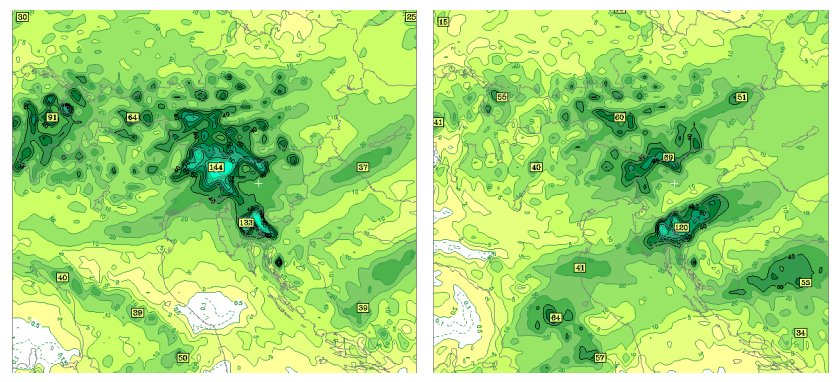

Fig. 2. The forecast using ALADIN/SI model for the total 24$\mathrm{h}$ precipitation in mm issued on 17.9.2007 00:00 UTC left panel and on 18.9.2007 at 00:00 UTC right panel, in both cases given for 19.9.2007 at 06:00 UTC.

resolution and $400 \mathrm{~s}$ time step is used by ARSO for forecasting purposes. This model issued on 17.9.2007 at 00:00 UTC underestimated (forecast for total 24-h precipitation on 18.9.2007: $144 \mathrm{~mm} / 24 \mathrm{~h}$ ) the actual measured precipitation (actual rainfall rates: $25 \mathrm{~mm} / 3 \mathrm{~h}, 50 \mathrm{~mm} / 6 \mathrm{~h}$, and $300 \mathrm{~mm} / 24 \mathrm{~h}$ ) in the SW part of Slovenia. Furthermore, it forecast very strong secondary rainfall maximum in the $\mathrm{S}$ Slovenia $(133 \mathrm{~mm})$ that actually did not happen (Fig. 2 left). The model issued on 18.9.2007 at 00:00 UTC was even much worse in predicting location and rainfall amounts to happen on that day (Fig. 2 right), a situation that has already happened before that a 48-h forecast turned out to be better than a 24-h one. Due to its rather coarse spatial resolution, the ALADIN/SI model in its present form seemed to be unable to more accurately predict the storm development occurring at a local spatial scale.

Also Poor Man's Ensemble Prediction System using 14 models probability forecast on 17.9.2007 12:00 UTC gave only $35 \%$ probability for $100 \mathrm{~mm}$ precipitation accumulation in $24 \mathrm{~h}$ for the period 18.9.2007 06:00 UTC to 19.9.2007 06:00 UTC (Strajnar, 2008). This Ensemble Prediction System of meteorological models is done automatically on a regular basis; therefore, no post-event recalculation of the meteorological models was needed. The operational radar also substantially underestimated the actual ground rainfall accumulation for $50 \%$. A comparison between radar reflectivity data from the meteorological radar positioned at Lisca for 18.9.2007 10:00 UTC and the measured rainfall accumulations from the automatic meteorological stations shown on a map of radar total precipitation from 18.9.2007 06:00 UTC till 19.9.2007 06:00 UTC is shown in Fig. 3. A study on radar observations for this event revealed that the major sources of radar underestimation were I) beam occlusion by orography; II) attenuation, due to the strong rainfall intensity; III) vertical profile of radar reflectivity, given the distance between the impacted basins in W Slovenia and the radar site on Lisca (Bouilloud et al., 2009).

The extreme rainfall on 18 September 2007 was also tracked on numerous rain gauging stations, mainly staff 

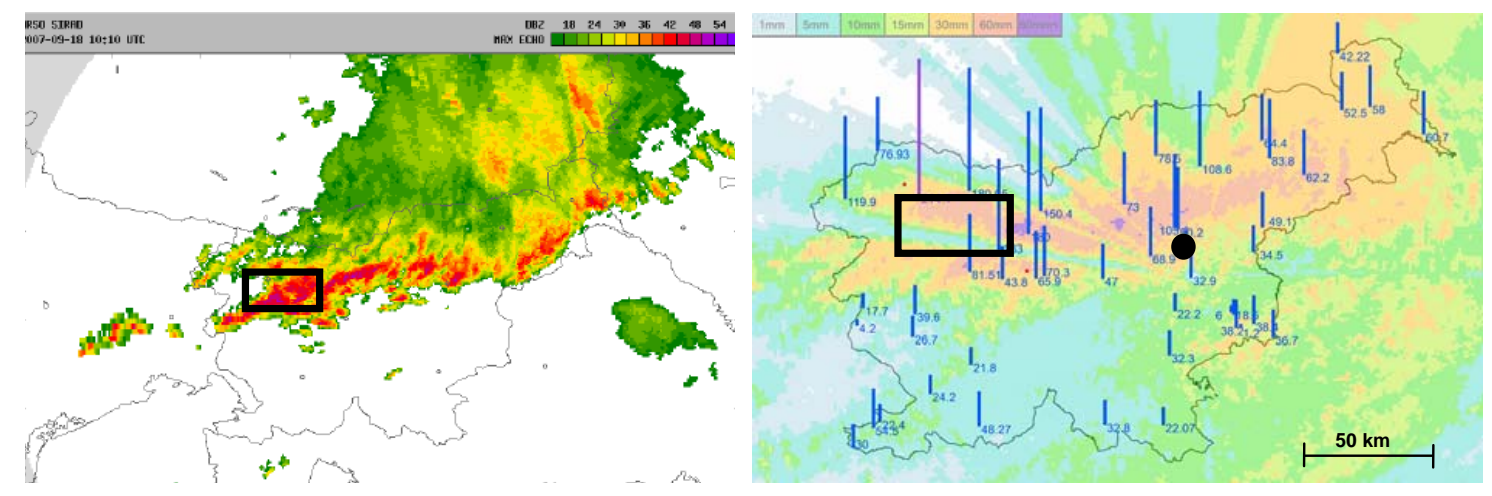

Fig. 3. Left panel: Measured radar reflectivity data from the meteorological radar at Lisca operated by the ARSO, given for 18 September 2007 at 10:00 UTC. Intensity of precipitation increases from green (week) through yellow (moderate) and red (strong) to violet (very strong). Right panel: Measured rainfall accumulations from the automatic meteorological stations shown on a map of radar total precipitation from 18.9.2007 06:00 UTC till 19.9.2007 06:00 UTC, black dot indicates the position of the meteorological radar at Lisca, black frame borders the area shown in Fig. 1 (ARSO, 2007a).
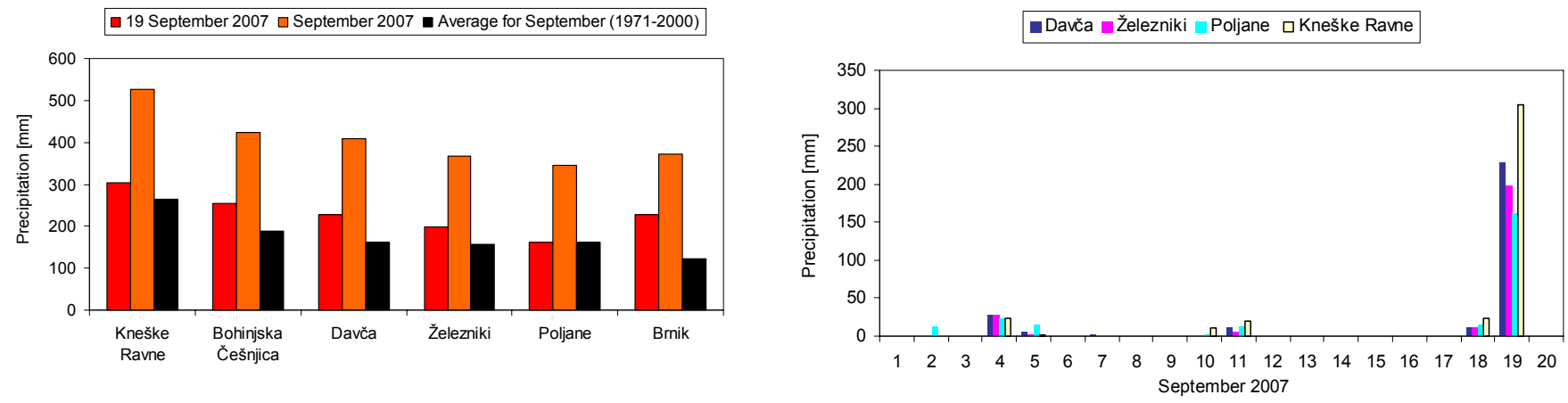

Fig. 4. Left panel: Long term average monthly rainfall in September and rainfall amounts measured in September 2007. Right panel: Daily rainfall in September 2007 on selected raingauges. For the position of the raingauges see Fig. 1.

gauges, some automatic rain gauges and meteorological stations operated by ARSO. The radar derived rainfall accumulations are mostly below $60 \mathrm{~mm} / 24 \mathrm{~h}$, and therefore massively underestimated. One can see how difficult is the estimation of actual extreme ground rainfall accumulations in NW Slovenia that is rather far away from the radar in Lisca and partially hidden by mountain ridges, a fact known to be valid for this part of Slovenia (Brilly and Rakovec, 1996). Furthermore, high spatial distribution of rainfall can be distinct even from the daily sums of the rainfall on gauging stations. High differences in the amount of precipitation were detected at small distances. The rainfall distribution for shorter rainfall duration was undoubtedly much higher, however recorded only on few automatic rain gauges. The amount of rainfall decreased towards the east and also towards the south.

\subsection{Hydrological situation and discharge data}

There was not a lot of precipitation in the northern part of Slovenia from the beginning of September 2007 (Fig. 4) revealing dry antecedent soil moisture conditions, river discharges were low early in the morning of 18.9.2007. Only some rivers in eastern and western part of the country had mean yearly discharges. A night before, rivers in southwestern part of the country raised slightly, but in the morning they were all decreasing. Regarding the meteorological situation on 18.9.2007, the northwest part of Slovenia got the highest amount of precipitation and the hydrological situation was critical in numerous catchments. In terms of rainfall sums, critical hydrological situation occurred at the Vogel Mountain, Kneške Ravne and Davča rainfall stations. The highest rainfall was measured at Vogel rainfall station; the Vogel mountain areas is known to receive very high rainfall (among highest rainfall amounts in Slovenia; long term average of yearly rainfall close to $3000 \mathrm{~mm}$ ). The rainfall on 18 September 2007 was thus in statistical sense not as 
extreme ( 25 year return period for daily rainfall) as at the stations nearby (i.e. Kneške Ravne - 50 year return period; Davča $>100$ year return period for daily rainfall).

In only a few hours very intensive precipitation in the area of northwest Slovenia caused local flooding of streams in the torrential catchments of the Bohinj area and to the west of Železniki (Davča, Fig. 1). On rainfall gauge in Davča $80 \mathrm{~mm}$ of rain was registered in only $50 \mathrm{~min}$. The Davča torrent in the village of Davča and the Selška Sora River in the town of Železniki rose extremely quickly and caused destruction and devastation, the most in Davča and Železniki, where three people lost their lives. The water station at Železniki was not damaged, however, the equipment stopped working before the hydrograph rise and the flood wave was unfortunately not recorded. The highest water level $551 \mathrm{~cm}$ was determined by the flood trace (Fig. 5) and it happened around 13:30. The Selška Sora River exceeded the highest water level recorded so far. The peak discharge was estimated to approximately $300 \mathrm{~m}^{3} / \mathrm{s}$ by extrapolation of the rating curve, and it exceeded by far 100-year return period determined statistically from flood peaks in the period of observation 1991-2006. The highest discharge from this period at the station in Železniki was $148 \mathrm{~m}^{3} / \mathrm{s}$ that occurred in 1995 (Kobold, 2008).

Measured travel times of the past floodwaves between the Železniki and Vešter water stations were between 1 and $2 \mathrm{~h}$ due to the fact that the Selška Sora River valley becomes much wider in this section (Fig. 1). On 18.9.2007 the Selška Sora floodwave propagation downstream towards the water station Vešter was slowed down to close to $3 \mathrm{~h}$ primarily owing to intensive flooding of the wider valley bottom. At water station Vešter near the city of Škofja Loka, which is positioned about $15 \mathrm{~km}$ downstream of Železniki, the hydrograph peak reached $353 \mathrm{~m}^{3} / \mathrm{s}$ at $16: 15$ local time (Kobold, 2008). According to the statistical analysis of the discharges at the Vešter water station, the hydrograph peak at the Vešter water station had a 25-year return period considering the period of observations from 1988 onwards. Near Škofja Loka, high waters of Selška Sora River flooded the confluence with the Poljanska Sora River, which remained low as its hydrograph peak did not exceed 2-year return period. Downstream of the confluence, at the Suha water station on the Sora River, the peak discharge of the combined discharges of the Selška and Poljanska Sora reached $440 \mathrm{~m}^{3} / \mathrm{s}$, which is a discharge with a return period of only $5-10$ years.

\section{Results and discussion}

\subsection{Analysis of the extreme rainfall event}

Through the analysis of the rainfall event on 18.9.2007, we wanted to obtain an insight into the local spatial phenomena of the extreme rainfall measured at adjacent rain gauges. Unfortunately, only few rain gauge stations in the area under investigation (NW part of Slovenia) are automatic; however

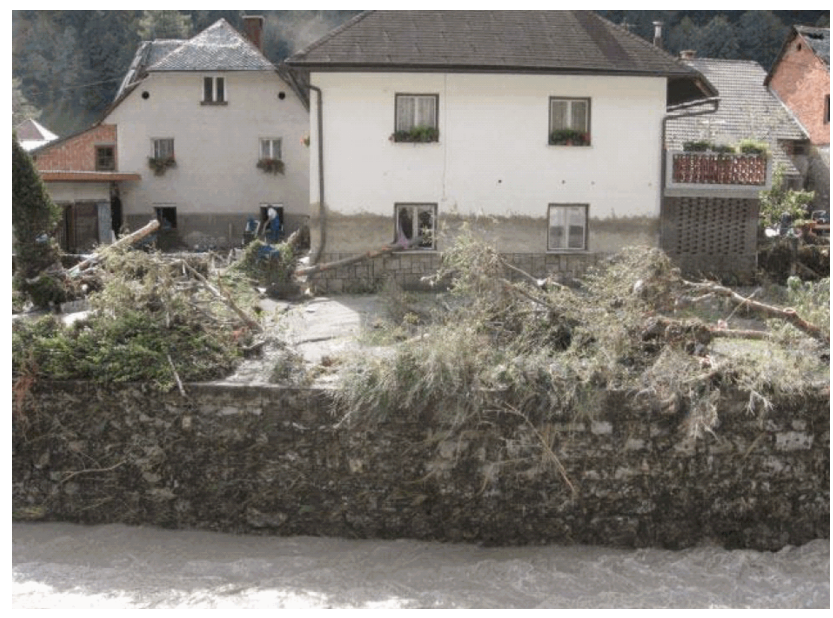

Fig. 5. Flood trace on a building used for peak water level assessment in Železniki (photo: Urban Ilc).

interestingly, highly spatially variable rainfall amounts and associated return periods are also evident from daily sums of the rainfall. If concentrating on a small area which partially also covers the Selška Sora catchment (Fig. 1), highly variable return periods were assessed for the rainfall amounts measured at rain gauges at this small area. The statistical analysis of the rainfall measured in rainfall stations is done by ARSO using Gumble distribution. Some rain gauges in the area measured rainfall amount of 25 to 50-year return period (e.g. Vogel and Kneške Ravne raingauge stations), whereas the return period for the gauge station Davča was estimated at more than 100 years. Due to short rainfall records at most of the rainfall stations, for the statistical analysis of the return periods, also other statistical distributions other than Gumble (e.g. GEV) should be used. A role of the sampling error as a consequence of short records used when assessing areal rainfall for hydrological modeling becomes presumably additionally increased by high spatial rainfall variability which can be observed at the Selška Sora catchment area.

For example, if comparing two stations, Davča rain gauge (24-h rainfall sum $228 \mathrm{~mm}$, assessed return period 250 years; highest observed daily sum of $117.2 \mathrm{~mm}$ in 1965) and Kneške Ravne rain gauge (24-h rainfall sum 304 mm, assessed return period of 50 years; highest observed daily sum of $237.3 \mathrm{~mm}$ in 1995), we can see that rainfall amounts were indeed extreme, but the difference in the assessment of the return period could be also exaggerated to some extent and not only a consequence of a highly variable rainfall event. The dispersion in the assessment of the return periods is to some extent also a consequence of statistical analysis of the daily rainfall which is based on the data series of 45 years (1963-2007), even though the long term mean of the annual maximum daily rainfall measured in this period is as follows: $85.1 \mathrm{~mm}$ in Davča and $165.5 \mathrm{~mm}$ in Kneške Ravne, respectively. 
Table 1. The highest short duration rainfall rates measured in selected pluviographs and automatic meteorological stations (AMS) on 18 September 2007 (ARSO, 2007a; ARSO, 2007b).

\begin{tabular}{|c|c|c|c|c|c|}
\hline \multirow[t]{2}{*}{ Measuring station } & \multicolumn{5}{|c|}{$\begin{array}{l}\text { Maximal short duration rainfall rates (given in } \mathrm{mm} \text { ) for } \\
\text { selected rainfall duration }\end{array}$} \\
\hline & $30 \mathrm{~min}$ & $60 \mathrm{~min}$ & $120 \mathrm{~min}$ & $360 \mathrm{~min}$ & $720 \mathrm{~min}$ \\
\hline Kneške Ravne & 53 & 84 & 157 & 240 & 297 \\
\hline Bohinjska Češnjica & 58 & 95 & 132 & 218 & 279 \\
\hline Vogel & 53 & 78 & 114 & 215 & 289 \\
\hline Davča & 58 & 84 & 111 & 155 & 214 \\
\hline Brnik & 18 & 32 & 57 & 120 & 176 \\
\hline
\end{tabular}

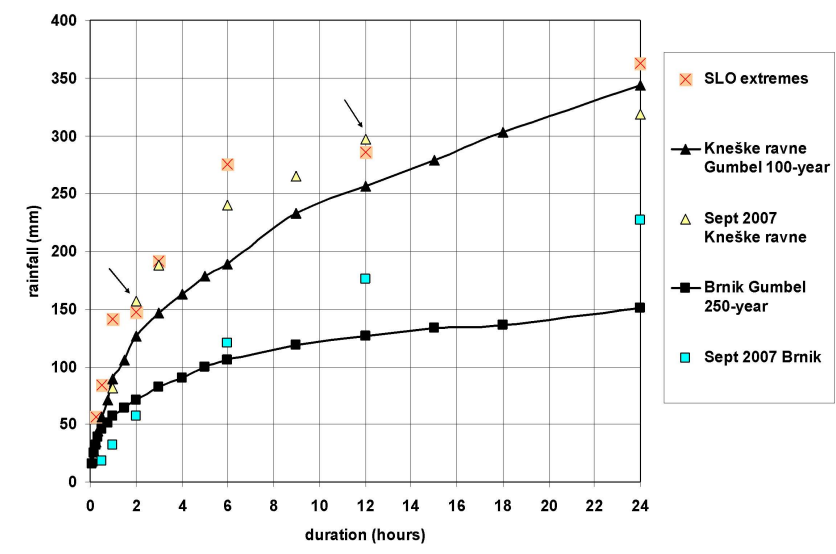

Fig. 6. Comparison of measured rainfall on the 18.9.2007, official statistically estimated extreme values given by ARSO for automatic rain gauges and the extreme values measured so far in Slovenia.

For additional analysis of the specific, spatially highly variable rainfall event, we have further investigated the highest short duration rainfall on selected automatic rain gauge stations and automatic meteorological stations in NW Slovenia. The highest short duration rainfall rates measured in selected automatic rain gauges and automatic meteorological stations (AMS) on 18.9.2007 are given in Table 1. The highest 30-minutes rainfall intensities were measured on Davča and Bohinjska Češnjica rain gauge $(58 \mathrm{~mm})$, whereas the highest 12-h rainfall was measured on Kneške Ravne $(297 \mathrm{~mm})$ and Vogel rain gauge $(289 \mathrm{~mm})$ (Fig. 1).

For a comparison, the highest rainfall rates measured so far in the meteorological network of ARSO are given in Table 2. In Fig. 6 measured rainfall on the 18.9.2007, and official statistically estimated extreme values given by ARSO for automatic rain gauges and the extreme values measured so far in Slovenia are compared. One can see that in the case of the Kneške Ravne automatic rain gauge (measurements in the period 1975-2007), the rainfall intensities were statistically the most critical (well above the curve of the rainfall intensities with 100-year return period) in the time span between
2 and $12 \mathrm{~h}$; moreover, the rainfall of that duration is comparable with and even exceeds the most extreme values measured so far in Slovenia (Table 2). On the contrary, the daily sum of rainfall at Kneške Ravne rain gauge on 18.9.2007 was below the curve of the 100-year return period rainfall. The return periods for the 5-min rainfall data at Kneške Ravne automatic rain gauge assessed by Gumbel distribution using L-moments were as follows: 1-h rainfall (50-year return period); 2-h rainfall (295-year return period); 3-h rainfall (326year return period); 6-h rainfall (327-year return period); 9$\mathrm{h}$ rainfall (189-year return period); 12-h rainfall (222-year return period) and 24-h rainfall (64-year return period), respectively. Such high return periods are nevertheless comparable if not so extreme as those estimated for the similar extreme rainfall event in the neighbouring eastern Italian Alps on 29 August 2003 (Norbiato et al., 2007).

However, at Brnik automatic rain gauge (Fig. 1, measurements in the period 1970-1993 and 2004), the rainfall intensities on 18.9.2007 for periods 6 to $24 \mathrm{~h}$ were well above the curve of statistically defined rainfall intensities with 250year return period (Fig. 6) which could indicate a serious underestimation of rainfall intensities for the mentioned time spans at that particular automatic rain gauge. Although the reported rainfall at gauge station Brnik was statistically labeled as extreme, interestingly, no high damage was reported at the Brnik flat areas, apart from traffic difficulties due to flooding of roads.

\subsection{Analysis of the hydrological situation}

The flash flood in the Selška Sora catchment was an extreme hydrological event. The drainage area of the catchment to Železniki is $104 \mathrm{~km}^{2}$ and downstream to Vešter $213.8 \mathrm{~km}^{2}$. Due to problems with measuring equipment in Selška Sora at Železniki, the flood wave was not recorded, thus the simulation of flood wave at Železniki was done by HEC-1 hydrological modeling system (Kobold, 2008). The primary data input for the model was rainfall from the rain gauge and meteorological stations in the catchment assessed by Thiessen polygons; field investigations of the water levels were used for initial rough assessment of the flood wave 
Table 2. Maximal rainfall rates measured so far in the meteorological network of the ARSO (ARSO, 2008).

\begin{tabular}{cccc}
\hline Maximum & Measuring station & $\begin{array}{c}\text { Rainfall rate } \\
{[\mathrm{mm}]}\end{array}$ & $\begin{array}{c}\text { Date } \\
\text { [dd.mm.yy h:min] }\end{array}$ \\
\hline 2-day (2880-min) & Bovec & $584 \#$ & $12.11 .697: 00-14.11 .697: 00$ \\
1-day (1440-min) & Bovec & $363 \#$ & $13.11 .697: 00-14.11 .19697: 00$ \\
12-h (720-min) & Bovec & 286 & 04.08 .87 13:00-05.08.87 01:00 \\
6-h (360-min) & Bovec & 275 & $04.08 .8715: 40-21: 40$ \\
3-h (180-min) & Kekec (Nova Gorica) & 191 & $21.08 .88 .08: 45-11: 45$ \\
2-h (120-min) & Kekec (Nova Gorica) & 147 & $21.08 .88 .08: 50-10: 50$ \\
1-h (60-min) & Kekec (Nova Gorica) & 141 & $21.08 .88 .08: 50-09: 50$ \\
30-min & Kekec (Nova Gorica) & 84 & $21.08 .88 .09: 00-09: 30$ \\
15-min & Ilirska Bistrica & 56 & $21.07 .8510: 10-10: 25$ \\
\hline
\end{tabular}

\# measured by classical rain gauge, effective values may be even somewhat higher.

peaks according to the extrapolated rating curve for the water station Železniki. The simulated hydrograph for Železniki water station is shown in Fig. 7.

According to the modeling results, the peak of flood wave is estimated to $278 \mathrm{~m}^{3} / \mathrm{s}$ at $13: 45$, what means $2.67 \mathrm{~m}^{3} / \mathrm{s} / \mathrm{km}^{2}$ of maximum specific runoff. A similar estimation for the peak discharge of $300 \mathrm{~m}^{3} / \mathrm{s}$ was made by a group of international experts after a post-event field survey in the area in November 2007 (Robič, 2008). The cumulative areal precipitation for the Selška Sora River catchment to Železniki amounts to $219 \mathrm{~mm}$, while the modeled effective precipitation used to simulate the hydrograph peak in combination with Snyder unit hydrograph was only $57 \mathrm{~mm}$. The modeled direct runoff coefficient therefore amounts to 0.26 . Surprisingly low value is mainly caused by the applied unit hydrograph method that seeks to meet the peak discharge rather than hydrograph volume. This fact could be confirmed by water level readings at Železniki water station on the recession limb of the hydrograph on 19.9.2007 that were higher than modeled values by a factor more than 3 . Using this data would raise the modeled direct runoff coefficients, however they cannot be directly applied due to raised river bed of the Selška Sora in the cross section of the Železniki water station (rise of the river bed around $0.5 \mathrm{~m}$ measured on 21.9.2007).

Figure 8 shows the hydrograph recorded at the water station Vešter. The amount of precipitation decreased downstream. In the Selška Sora catchment between Železniki and Vešter, the average areal precipitation amounts to $187 \mathrm{~mm}$; i.e. $32 \mathrm{~mm}$ less precipitation than in the upper part of the catchment upstream of Železniki. According to the measured flood wave at the water station Vešter and areal precipitation at the Selška Sora catchment upstream of the Vešter water station, the total runoff coefficient amounted 0.32 which is rather low considering the high rainfall intensities for the periods between 2 and $12 \mathrm{~h}$ for which one would expect to greatly exceed the soil infiltration capacity. However, the spatial distribution of the rainfall in the area upstream of the

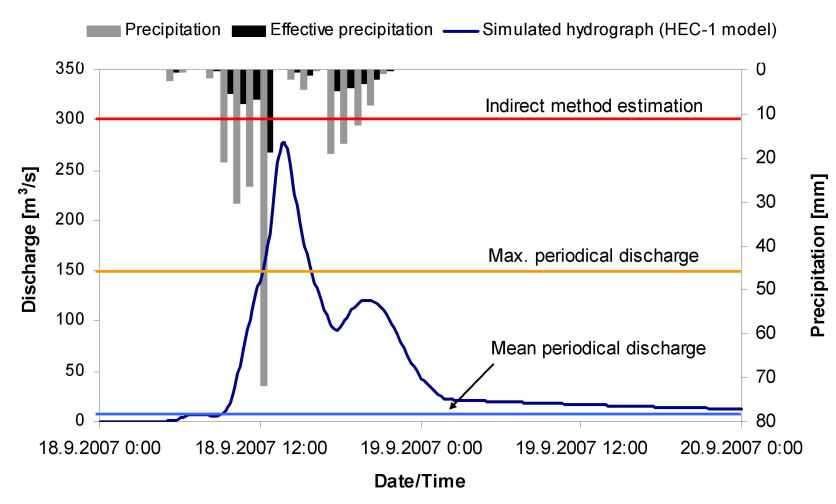

Fig. 7. Simulated hydrograph of the Selška Sora River at Železniki using HEC-WMS model, periodical mean and maximal discharges and areal precipitation to Železniki.

water station Vešter was highly variable and present spatial positioning of rain gauges is obviously inadequate for proper representation of the actual spatial amount of rainfall that could have been substantially different from the amount we have used for hydrological modeling. Namely, relatively low total runoff coefficients can be partially attributed to dry antecedent soil moisture conditions and to a lesser extent associated to vegetation interception losses in September in predominantly forested Selška Sora catchment.

On the other hand, geological structure of the Selška Sora catchment is not uniform; the northern part of the catchment is more permeable (calciferous formations) whereas the southern part is much less permeable (mainly marl and slate) leading to non-uniform hydrological response of the catchment. At least in the part of the catchment with calciferous formations it is likely that very intense rainfall (short showers) efficiently infiltrated into rather shallow soils and partially drained into fractured bedrock. Due to shallow depths, soil saturation was rather fast and therefore also subsurface circulation and not just overland flow was present. 


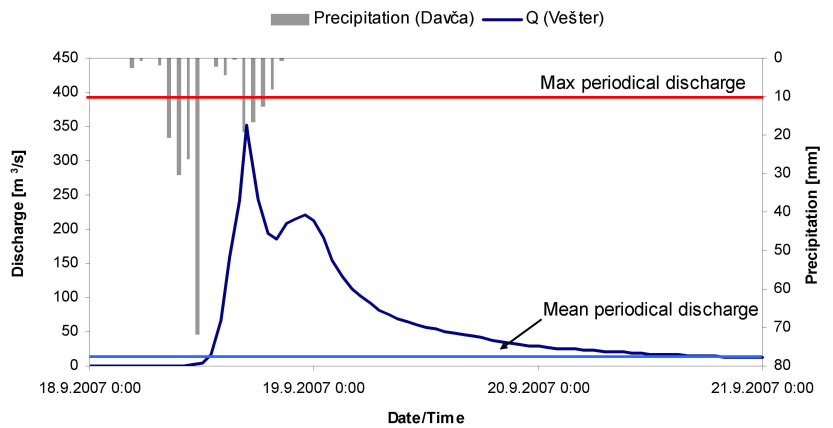

Fig. 8. Hydrograph of the Selška Sora River at Vešter water station with periodical mean and maximal discharges and hourly intensity of rainfall in Davča.

Was this hydrological situation favorable for triggering soil slips and slides? Yes, though shallow soil depth was presumably the main reason why during this extreme rainfall event only reasonably limited number of shallow slips and slides have been observed (on 18.9.2007 altogether 432 slips and slides have been reported all over Slovenia), and not also deep-seated landslides. In many cases, these soil slips have not even reached the hydrological network and therefore sediment supply was limited. Furthermore, locally some debris flows have been triggered after break-up of local damming of woody debris. Generally, we may conclude that sediment supply and sediment transport was less intense as one would expect for such an extreme rainfall event.

\subsection{Consequences}

Extraordinary meteorological situation on 18.9.2007, and the consequent flash floods claimed 6 casualties. The first damage estimation was assessed to 210 million Euros of economic damage, but after a year lowered to less than 200 million Euros. Out of 210 municipalities in Slovenia, 60 were reporting flood damages.

Such a devastating flash flood in Slovenia has not been experienced since the September 1926 flood in Ljubljana, the capitol of Slovenia. During this event, rainfall amounts between 300 and $500 \mathrm{~mm}$ were observed in two days. Due to steady economic development in Slovenia, damage potential is increasing, especially in flood-prone areas. In near future, extreme rainfall events may be expected to cause increasing economic damages; floods in August 2005 in Switzerland caused approximately 2 billion Euro of direct economic damages, the highest financial damages caused by a single natural event since 1972 (UVEK, 2008).

According to the meteorological and hydrological situation, the flash flood event in Železniki has many typical characteristics which make the analysis of the flash flood events difficult, not mentioning the possibilities to make a prediction of the occurrence of such an event in advance. Also damming of woody debris, mainly flushed from forested headwaters, and had locally worsened the flood situation (Mikoš, 2007).

\section{Conclusions}

Some highest rainfall rates ever measured in Slovenia can be claimed during the extreme event on 18.9.2007. In many localities estimated rainfall return periods were higher or even much higher than 100 years (around 250 years). Unfortunately, available time series from raingauges for rainfall duration less than $24 \mathrm{~h}$ are in many places too short (only 20-30 years) for a robust statistical analysis and a reliable estimation of return periods of the measured extreme rainfall on these locations. The study described in this paper confirmed that post-flood investigation should focus on discharges and hydrological response of the catchment rather than simply analyzing statistical characteristics of rainfall. Therefore, measured rainfall data were used to reconstruct hydrographs on selected water stations along the Selška Sora River yielding low runoff coefficient. Used hydrological models were able to rather well reconstruct the hydrograph peaks; however, the runoff volumes were considerably underestimated.

Even though the occurrence, location and (or) timing of a flash flood is generally still uncertain, some efforts have been made so far in developing the procedures which may provide enough lead time so that flash flood mitigation measures can be planned and managed in an anticipatory rather than responsive manner (Norbiato et al., 2008). The provision of information about flash flood susceptibility is one of the objectives of the flash flood guidance method, which is in operation in the United States since 1970s (Mogil et al., 1978). According to Georgakakos (2006), the US National Weather Service relies routinely on flash flood guidance computations to produce flash flood warnings.

The analysis of characteristics of the extreme rainfall event and consequent flash floods in W Slovenia in September 2007 have shown that further improvements are needed with regard to our early warning and possible evacuation as an immediate measure. It is therefore essential to improve meteorological models for early warning and now-casting in the case of flash floods. There are several already available meteorological models nowadays used as research models with the resolution of e.g. $1 \mathrm{~km}$ (Žagar, 2008) that are promising tools for meteorologists to be able to better forecast future extreme rainfall events and issue better flash floods warnings. Important steps towards improved early warning system in Slovenia for the cases of extreme rainfalls of short duration causing flash floods would be installation of additional automatic raingauges with remote data updating and second meteorological radar in W Slovenia. Furthermore, usage of these meteorological data in the INCA analysis (Integrated Now-casting with Comprehensive Analysis) and nowcasting system (Strajnar, 2008) for short-term $(0-2 \mathrm{~h})$ forecast is another step towards more effective early warning system for flash floods. 
Acknowledgements. This research was funded by the Ministry of Higher Education, Science and Technology of the Republic of Slovenia, research programme No. P2-180-0792 "Hydrotechnics, Hydraulics, and Geotechnics". The rainfall data measured in selected gauging stations and used in this study for the statistical analysis of the event were kindly provided by the Environmental Agency of the Republic of Slovenia. The authors thank two anonymouos reviewers that help to substantially improve the paper.

Edited by: R. Kirnbauer

Reviewed by: two anonymous referees

\section{References}

ARSO: Izjemen padavinski dogodek 18. septembra 2007 (Extreme rainfall event on 18.9.2007 - in Slovenian), http://www.arso.gov.si/vreme/poro\%c4\%8dila\%20in\%

20projekti/padavine_18sep07.pdf, last access: 13.11.2007, Environmental Agency of the Republic of Slovenia, Ljubljana, 17 p., 2007a.

ARSO: Poročilo o vremenski in hidrološki situaciji 18. septembra 2007 (A report on the meteorological and hydrological situation on 18. September 2007 - in Slovenian), http://www.arso.gov.si/vode/publikacije\%20in\%20poro\% c4\%8dila/visoke_vode20070918.pdf, last access: 24.9.2007, Environmental Agency of the Republic of Slovenia, Ljubljana, 23 p., 2007b.

ARSO: Slovenski vremenski rekordi (Slovenian meteorological records - in Slovenian), http://www.arso.gov.si/vreme/podnebje/ slo_vremenski_rekordi.pdf, (access: 23.12.2008) Environmental Agency of the Republic of Slovenia, Ljubljana, 5 p., 2008.

Baldini, L., Facheris, L., Giuli, D., Caporali, E., and Palmisano, E.: Analysis of radar and raingage measurements for a critical meteorological event in Tuscany, Surv. Geophys., 16, 253-264, 1995.

Borga, M., Boscolo, P., Zanon, F., and Sangati, M.: Hydrometeorological analysis of the August 29, 2003 flash flood in the eastern Italian Alps. J. Hydrometeorol., 8(5), 1049-1067, 2007.

Bouilloud, L., Delrieu, G., Boudevillain, B., Zanon, F., and Borga, M.: Radar rainfall estimation for the post-event analysis of a Slovenian flash-flood case: application of the mountain reference technique at C-band frequency, Hydrol. Earth Syst. Sci. Discuss., 6, 667-696, 2009,

http://www.hydrol-earth-syst-sci-discuss.net/6/667/2009/.

Brilly, M. and Rakovec, J.: Use of radar for flood forecasting. Acta Hydrotechnica, 14(12), 123-136, 1996.

Chappell, C. F.: Quasi-stationary convective events, in: Mesoscale Meteorology and Forecasting edited by: Ray, P. S., Amer. Meteor. Soc., 289-310, 1986.

Costa, J. E. and Jarrett, R. D.: An evaluation of selected extraordinary floods in the United States reported by the US, Geological Survey and implications for future advancement of flood science, USGS, Scientific investigations, Report 2008-5160, Reston, Virginia, 2008.

Creutin, J. D. and Borga, M.: Radar hydrology modifies the monitoring of flash flood hazard. Invited commentary, Hydrol. Process., 17(7), 1453-1456, 2003.

Delrieu, G., Ducrocq, V., Gaume, E., Nicol, J., Payrastre, O., Yates, E., Kirstetter, P.-E., Andrieu, H., Ayral, P.-A., Bouvier,
C., Creutin, J.-D., Livet, M., Anquetin, S., Lang, M., Neppel, L., Obled, C., Parent-du-Châtelet, J., Saulnier, G.-M., Walpersdorf, A., and Wobrock, W.: The Catastrophic Flash-Flood Event of 8-9 September 2002 in the Gard Region, France: A First Case Study for the Cévennes-Vivarais Mediterranean Hydrometeorological Observatory, J Hydrometeorol., 6, 34-52, 2005.

Doswell, III, C. A., Ramis, C., Romero, R., and Alonso, S.: A diagnostic study of three heavy precipitation episodes in the western Mediterranean, Weather Forecast., 13, 102-124, 1998.

Fritsch, J. M., Houze, R. A., Adler, R., Bluestein, H., Bosart, L., Brown, J., Carr, F., Davies, C., Johnson, R. H., Junker, N., Kuo, Y.-H., Rutledge, S., Smith, J., Toth, Z., Wilson, J. W., Zipser, E., Zrnic, D.: Quantitative precipitation forecasting: report of the eighth prospectus development team, US weather research program, B. Am. Meteorol. Soc., 79, 285-299, 1998.

Gaume, E., Livet, M., Desbordes, M., and Villeneuve, J.-P.: Hydrological analysis of the River Aude flash-flood on 12 and 13 November 1999, J. Hydrol., 286, 135-154, 2004.

Gaume, E. and Borga, M.: Post-flood field investigations in upland catchments after major flash floods: proposal of a methodology and illustrations, J. Flood Risk Manag., 1, 175-189, 2008.

Georgakakos, K. P.: Analytical results for operational flash flood guidance, J. Hydrol., 317(1-2), 81-103, 2006.

Kelsch, M., Caporali, E., and Lanza, L. G.: Hydrometeorology of flash floods, in: Coping with Flash Floods, edited by: Gruntfest, E. and Handmer, J., Kluwer Academic Publishers, Dordrecht, Nato Science Series 2 - Environmental security, 77, 19-35, 2001.

Kobold, M.: High waters and floods of 18 September 2007, Ujma, http://www.sos112.si/slo/tdocs/ujma/2008/065.pdf, last access: 19.12.2008, 22, 65-75, 2008.

Maddox, R. A., Chappell, C. F., and Hoxit, L. R.: Synoptic and meso-alpha scale aspects of flash flood events, B. Am. Meteorol. Soc., 60, 115-123, 1979.

Mikoš, M., Četina, M., and Brilly, M.: Hydrologic conditions responsible for triggering the Stože landslide, Slovenia, Eng. Geol., 73, 193-213, 2004.

Mikoš, M.: Upravljanje tveganj in nova Evropska direktiva o poplavnih tveganjih (Risk management and the new European Directive on flood risks), Gradbeni vestnik, 56, 278-285, 2007.

Mogil, H. M., Monro, J. C., and Groper, H. S.: NWS's flash flood warning and disaster preparedness programs, B. Am. Meteorol. Soc., 59, 690-699, 1978.

Montz, B. E.: Assessing the effects and effectiveness of flash flood mitigation strategies, in: Coping with Flash Floods, edited by: Gruntfest, E. and Handmer, J., Kluwer Academic Publishers, Dordrecht, Nato Science Series 2 -Environmental security, 77, 123-134, 2001.

Norbiato, D., Borga, M., Sangati, M., and Zanon, F.: Regional frequency analysis of extreme precipitation in the eastern Italian Alps and the August 29, 2003 flash flood, J. Hydrol., 345, 149166, 2007.

Norbiato, D., Borga, M., Esposti, S. D., Gaume, E., Anquetin, E.: Flash flood warning based on rainfall thresholds and soil moisture conditions: An assessment for gauged and ungauged basins, J. Hydrol., 362, 274-290, 2008.

Ogden, F. L., Sharif, H. O., Senarath, S. U. S., Smith, J. A., Baeck, M. L., and Richardson, J. R.: Hydrologic analysis of the Fort Collins, Colorado, flash flood of 1997, J. Hydrol., 228, 82-100, 2000 . 
Ramos, M. H., Creutin, J. D., and Leblois, E.: Visualization of storm severity, J. Hydrol., 315, 295-307, 2005.

Robič, M.: Investigating floods in the Selška Sora Valley, on 18 September 2007, with Hydrate international group, http://www.sos112.si/slo/tdocs/ujma/2008/111.pdf, last access: 19.12.2008, Ujma, 22, 111-116, 2008.

Rochette, S. M. and Moore, J. T.: Initiation of an elevated mesoscale convective system associated with heavy rainfall, Weather Forecast., 11(4), 443-457, 1996.

Ruin, I., Creutin, J. D., Anquetin, S., and Lutoff, C.: Human exposure to flash floods - Relation between flood parameters and human vulnerability during a storm of September 2002 in Southern France, J. Hydrol., 361, 199-213, 2008.

Schwein, N. O.: The Effect of Quantitative Precipitation Forecasts on River Forecasts, NOAA Technical Memorandum NWS-CR110, National Weather Service, Washington DC, 1996.

Strajnar, U.: Forecasting of Extreme Stationary Convection 18/9/2007 Zelezniki Flash Flood, http://ams.confex.com/ams/ pdfpapers/140913.pdf, last access: 24.7.2008, Extended Abstracts of the 13th Conference on Mountain Meteorology, 2008.
UVEK: Hochwasser 2005 in der Schweiz - Synthesisbericht zur Ereignisanalyse, http://www.umwelt-schweiz.ch/div-7529-d, last access: 19.12.2008, Eidgenössiches Departement für Umwelt, Verkehr, Energie und Kommunikation, Bern, 2008.

Vertačnik, G.: Climatological description of the exceptional precipitation event of 18 September 2007, http://www.sos112.si/slo/ tdocs/ujma/2008/058.pdf, last access: 19.12.2008, Ujma, 22, 5864, 2008.

Žagar, M.: Analysis of causes and numerical modeling of heavy precipitation on 18 September 2007, http://www.sos112.si/slo/ tdocs/ujma/2008/101.pdf, last access: 19.12.2008, Ujma, 22, 101-104, 2008. 